\title{
Myositis as a rare complication after tocilizumab treatment
}

\author{
Estefania Quesada-Masachs ${ }^{*}$, Consuelo Modesto Caballero \\ From 21st European Pediatric Rheumatology (PReS) Congress \\ Belgrade, Serbia. 17-21 September 2014
}

\section{Introduction}

Tocilizumab (TCZ) is an anti-interleukin-6 receptor antibody. It has been accepted as a biological treatment in some subtypes of Juvenile Idiopathic Arthritis. Offlabel it has been used (compassionate use) in some refractory pediatric autoimmune disorders. Despite being an effective treatment in most cases, this drug isn't exempt of adverse events.

\section{Objectives}

To describe a patient affected by an overlap autoimmune syndrome who presents an inflammatory myopathy as a rare complication during TCZ treatment.

\section{Methods}

A 6-year-old boy affected by an overlap autoimmune syndrome characterized by facial skin lesions chilblain lupus like (histopathologically compatible with leukocytoclastic vasculitis), recurrent skin urticarial episodes and a severe lung disease (in the anatomopathological study is a linfoid intersticial neumonitis). He presents antinuclear antibodies positivity (maximum title reported 1/640), an undetermined antiDNA antibodies title (values around $31 \mathrm{UI} / \mathrm{ml}$ ), no complement consumption of $\mathrm{C} 3$ neither $\mathrm{C} 4$, positives antiB2-glycoprotein and anticardiolipin IgG antibodies with persisting elevation of acute phase reactants highlighting an ESR permanently around $100 \mathrm{~mm} / \mathrm{h}$ and thrombocytosis around $500 \times 10^{\wedge} 9$ platelets. An extended auto-antibodies study was repeatedly performed without finding other auto-antibodies positivity. Several therapeutic strategies with different agents were previously tested (corticoids, azathioprine, hydroxychloroquine, anakinra, mycophenolate, gammaglobulin, tacrolimus). All of these therapies

Pediatric Rheumatology, Hospital Universitari Vall d'Hebron, Barcelona, Spain were discontinued because of inefficacy or lack of efficacy, and resolution of symptoms wasn't achieved.

\section{Results}

After a multidisciplinary evaluation TCZ treatment was initiated. After the first dose he presented improvement of general condition, of skin lesions and of the exertional dyspnea and a dramatical decrease in the acute phase reactants values. Two months later he referred subacute inflammatory pain in both lower limbs, predominantly proximal and symmetrical. The blood test revealed elevation of liver and muscular enzymes: alanine aminotransferase $91 \mathrm{UI} / \mathrm{L}$, aspartate aminotransferase $59 \mathrm{UI} / \mathrm{L}$, creatine kinase $1008 \mathrm{UI} / \mathrm{L}$, aldolase $34.3 \mathrm{UI} / \mathrm{L}$, lactate dehydrogenase $695 \mathrm{UI} / \mathrm{L}$. A bilateral lower limb MRI was performed confirming enhanced STIR signal and edema affecting multiple muscles: right transverse abdominal muscle, bilateral gluteal muscles (maximus, medius and minimus), almost all muscle groups in both thighs respecting the intermedius and medialis vastus, the short and long adductors, and partially the magnus adductor. Inflammatory lesions of practically all muscle groups respecting the posterior tibial and soleus muscles in both legs were also observed. To sum up, a bilateral inflammatory myopathy was detected from abdomen to ankles. Intravenous gammaglobulin $1 \mathrm{mg} / \mathrm{kg} / 14$ days treatment was introduced and TCZ discontinued achieving a fast improving in pain, function and normalizing blood parameters related with muscle inflammation. Two months later the myositis episode was on clinical and biological remission but the autoimmune disease continues.

\section{Conclusion}

We report a case of inflammatory myopathy attributed as a rare complication after Tocilizumab treatment. To our knowledge, this adverse event of Tocilizumab treatment wasn't previously described. 


\section{Disclosure of interest}

None declared

Published: 17 September 2014

doi:10.1186/1546-0096-12-S1-P345

Cite this article as: Quesada-Masachs and Caballero: Myositis as a rare

complication after tocilizumab treatment. Pediatric Rheumatology 201412 (Suppl 1):P345

Submit your next manuscript to BioMed Central and take full advantage of:

- Convenient online submission

- Thorough peer review

- No space constraints or color figure charges

- Immediate publication on acceptance

- Inclusion in PubMed, CAS, Scopus and Google Scholar

- Research which is freely available for redistribution

Submit your manuscript at www.biomedcentral.com/submit 